\title{
OPEN Effects of biotin on promoting anammox bacterial activity
}

\author{
Qinyu $\mathrm{Li}^{1,2}$, Jinhui Chen ${ }^{1,2}$, Guo-hua Liu ${ }^{1 凶}$, Xianglong Xu ${ }^{1 凶}$, Qian Zhang ${ }^{1}$, Yijin Wang ${ }^{1}$, \\ Junli Yuan ${ }^{1}$, Yinghao $\mathrm{Li}^{1}{ }^{1}$ Lu Oi $^{1}$ \& Hongchen Wang ${ }^{1}$
}

Anaerobic ammonium oxidation (anammox) bacteria significantly improve the efficiency and reduce cost of nitrogen removal in wastewater treatment plants. However, their slow growth and vulnerable activity limit the application of anammox technology. In this paper, the enhancement of biotin on the nitrogen removal activity of anammox bacteria in short-term batch experiments was studied. We found that biotin played a significant role in promoting anammox activity within a biotin concentration range of $0.1-1.5 \mathrm{mg} / \mathrm{L}$. At a biotin concentration of $1.0 \mathrm{mg} / \mathrm{L}$, the total nitrogen removal rate (NRR) increased by $112 \%$, extracellular polymeric substance (EPS) secretion and heme production significantly improved, and anammox bacterial biomass increased to maximum levels. Moreover, the predominant genus of anammox bacteria was Candidatus Brocadia.

Anaerobic ammonium oxidation (anammox) bacteria, a type of chemotrophic bacteria that uses bicarbonate as a carbon source, convert $\mathrm{NH}_{4}{ }^{+}$and $\mathrm{NO}_{2}{ }^{-}$into $\mathrm{N}_{2}$ under anaerobic or hypoxic conditions ${ }^{1}$. Owing to their low energy and organic carbon consumption, anammox improves the efficiency and reduces the cost of nitrogen removal in wastewater treatment ${ }^{2,3}$. Therefore, research in the field of novel biological processes is highly focused on anammox, and more than 100 full-scale anammox wastewater treatment plants (WWTPs) are in operation across the world ${ }^{4,5}$. Although anammox bacteria are widely distributed in natural ecosystems, their slow growth limits the application and promotion of anammox technology; anammox bacteria typically have a cell yield of $0.066 \pm 0.010 \mathrm{~mol} \mathrm{C} / \mathrm{mol} \mathrm{NH}_{4}{ }^{+}$, a cell-doubling time of 7-20 days, and a growth rate far lower than that of ordinary nitrifying bacteria ${ }^{6,7}$. In addition, anammox bacteria are sensitive to their external environment, including to factors such as illumination, temperature, $\mathrm{pH}$, dissolved oxygen (DO), and substrate ${ }^{8-11}$.

Multifarious methods have been used to maintain anammox biomass or accelerate anammox activity to enrich anammox bacteria. Several solutions have been proposed, such as the use of different types of seed sludge and appropriate reactor configurations, all of which have advantages and limitations ${ }^{12-21}$. However, few studies have reported on the promotion of the anammox process by vitamin $\mathrm{B}$, which is necessary for cell metabolism.

Biotin (vitamin B7) is a water-soluble vitamin that is essential for all organisms, from bacteria to humans ${ }^{22}$. In eukaryotic cells, biotin acts as a coenzyme, collectively known as carboxylase, which catalyzes key reactions in gluconeogenesis, amino acid catabolism, and fatty acid synthesis ${ }^{23,24}$. Biotin therefore promotes cell metabolism of sugar, fat, and protein and accelerates cell growth. Organisms also require biotin for carbon dioxide fixation, especially chemotrophic bacteria that use bicarbonate as a carbon source (e.g., anammox bacteria).

In this study, we assessed the short-term effects of different biotin doses on the biological activity and biomass of anammox bacteria. We also examined the effect of biotin on the anammox microbial community structure to determine the role of biotin in the anammox process. Our main aim was to identify the most feasible method for enhancing the growth and activity of anammox bacteria to reduce the start-up time of the anammox process in wastewater treatment.

\section{Materials and methods}

Synthetic wastewater. Synthetic wastewater containing substrates, bicarbonate, and trace elements was introduced into the experimental setup as the influent. The composition of the synthetic wastewater was similar to that described by Yang and $\mathrm{Jin}^{25}$. Ammonium and nitrite were supplied in the forms of $\mathrm{NH}_{4}{ }^{+}-\mathrm{N}^{-}$and $\mathrm{NO}_{2}{ }^{-}-\mathrm{N}$, respectively, and their initial concentrations in the influent were $80 \mathrm{mg} / \mathrm{L}$ and $104 \mathrm{mg} / \mathrm{L}$, respectively. The influent $\mathrm{pH}$ was $7.5 \pm 0.2$ without the addition of acid or alkali. The $\mathrm{DO}$ of the reactor was below the limits of detection.

\footnotetext{
${ }^{1}$ Low Carbon Water Environmental Technology Research Center, School of Environment \& Natural Resources, Renmin University of China, Beijing 100872, China. ${ }^{2}$ These authors contributed equally: Qinyu Li and Jinhui Chen.

『email: Igh@ruc.edu.cn; qsyxxl@ruc.edu.cn
} 


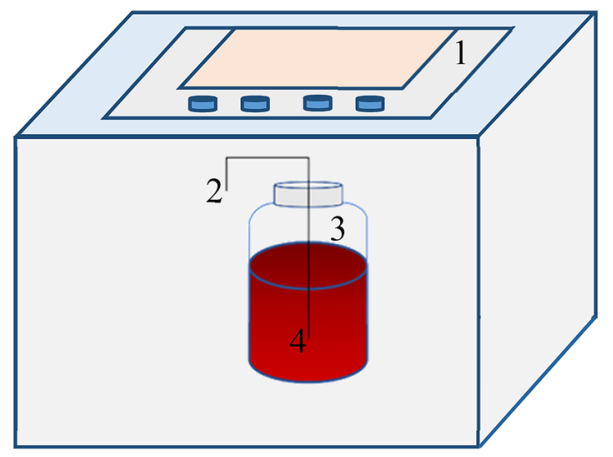

Figure 1. Schematic diagram of the reactor system: (1) Control panel for rotation speed and temperature, (2) sludge sample, (3) $\mathrm{N}_{2}$, and (4) serum bottle (with or without biotin).

Seed sludge. The anammox seed sludge with the diameter of $1.81 \mathrm{~mm}$ used in this study was obtained from a laboratory-scale anammox SBR reactor, with a sludge concentration of approximately $4500 \mathrm{mg} / \mathrm{L}$ and a nitrogen removal rate (NRR) of $41.2 \mathrm{mg} \mathrm{N} \mathrm{g}^{-1} \mathrm{VSS} \mathrm{d}^{-1}$. The seed sludge was washed with phosphate buffer $(140 \mathrm{mg} / \mathrm{L}$ $\mathrm{KH}_{2} \mathrm{PO}_{4}$ and $750 \mathrm{mg} / \mathrm{L} \mathrm{K}_{2} \mathrm{HPO}_{4}$ ) to eliminate the influence of background nitrogen.

Each serum bottle was inoculated with $3 \mathrm{~g}$ of sludge (wet weight). The initial biomass concentration and the ratio of the volatile suspended solids (VSS) to the suspended solids (SS) of the anammox sludge were $0.785 \pm 0.017 \mathrm{~g} \mathrm{VSS} \mathrm{L}^{-1}$ and $0.788 \pm 0.003$, respectively. The content of extracellular polymeric substances (EPS) was $145.2 \pm 5.6 \mathrm{mg} \mathrm{g}^{-1}$ VSS, and the content of heme was $1.65 \pm 0.3 \mathrm{mg} \mathrm{g}^{-1}$ VSS. The sludge was dominated by the anammox bacteria genus Candidatus Jettenia asiatica.

Experimental procedures. Several $500 \mathrm{~mL}$-serum bottles with $450 \mathrm{~mL}$ liquid-phase volume were used as the anammox reactors in this study, as shown in Fig. 1. To assess the performance of anammox with biotin, four serum bottles with different biotin concentrations were assigned as the four experimental groups. A serum bottle with the same conditions as the experimental groups but without biotin was used as the control. We wrapped the anammox reactors with aluminum foil to prevent light inhibition, and nitrogen was aerated into the reactor for $20 \mathrm{~min}$ to ensure the anaerobic state. The reactors were then placed in an air bath incubator (Changzhou, China) at $35 \pm 1{ }^{\circ} \mathrm{C}$, with a controlled rotation speed of $140 \mathrm{rpm}$.

Analysis of anammox bacterial activity. Batch experiments were performed with the serum bottles to measure the NRR, EPS, electron transport system (ETS) activity, heme, and gene copy number of anammox bacteria. These measured parameters were then used to assess the short-term impact of biotin stimulation on anammox activity.

Analytical methods. $3 \mathrm{~mL}$ of supernatant as water samples were routinely collected every day with injector from the serum bottle, and filtered through $0.45 \mu \mathrm{m}$ filter membranes to determine the $\mathrm{NH}_{4}{ }^{+}-\mathrm{N}, \mathrm{NO}_{2}{ }^{-}-\mathrm{N}$ and $\mathrm{NO}_{3}{ }^{-}-\mathrm{N}$ concentrations using the standard methods described by APHA. The VSS of the granular sludge was also measured using standard methods ${ }^{26}$. EPS was extracted using the methods described by Yu et al. ${ }^{27}$ The main components-proteins (PN) and polysaccharides (PS) - were analyzed according to the methods described by Lowery et al. ${ }^{28}$ and Dubois et al. ${ }^{29}$ respectively. The ETS activities were measured by the method described by Trevors et al. ${ }^{30}$ The heme content was determined using the method described by Meng et al..$^{31}$ Biotin concentrations were determined using the high-performance liquid chromatography (HPLC) method by Qi et al. ${ }^{32}$ Each of the experimental conditions was performed in triplicate to ensure experimental accuracy. The final data was the average of the triplicate results, and the standard deviation was calculated for subsequent analysis.

DNA extraction and quantitative polymerase chain reaction (qPCR) assay. DNA extraction, and then quantitative PCR analysis were performed on the initial and the after six days of cultivation's sludge under different concentrations of biotin. DNA was extracted from $0.5 \mathrm{~g}$ sample following the specifications of the FastDNA Spin Kit for Soil (MP, USA) for subsequent qPCR measurement. The DNA concentration was measured using a Nanodrop 2000 UV-Vis spectrophotometer (Nanodrop Technologies, Wilmington, DE, USA), and the gene copy number was calculated according to the concentration of plasmid DNA and the length of gene fragment. After obtaining the plasmid DNA, sterile water was used for continuous dilution to construct the standard curve. The amplification efficiency and correlation coefficient were greater than $105 \%$ and 0.98 , respectively. The abundance of anammox bacteria was determined using an ABI 7000 real-time PCR instrument (Eppendorf, Germany) using the TransStart Green qPCR SuperMix (Transgen Biotech, Beijing, China). The forward and reverse primers were Amx 809f $\mathrm{f}^{33}$ and Amx 1066r, respectively, and the primer information is shown in Table 1.

The total volume of the reaction system was $20 \mu \mathrm{L}$, including $10 \mu \mathrm{L}$ TransStart Green qPCR SuperMix, $1 \mu \mathrm{L}$

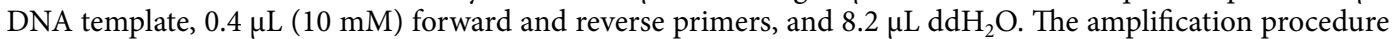
consisted of the following steps: $30 \mathrm{~s}$ at $94^{\circ} \mathrm{C}$, followed by 45 cycles of $10 \mathrm{~s}$ at $94^{\circ} \mathrm{C}, 15 \mathrm{~s}$ at $55^{\circ} \mathrm{C}$, and $15 \mathrm{~s}$ at $72{ }^{\circ} \mathrm{C}$. 


\begin{tabular}{|l|l|}
\hline Primer name & Sequence $\left(\mathbf{5}^{\prime}\right.$ - $\mathbf{3}^{\prime}$ ) \\
\hline AMX809f & GCCGTAAACGATGGGCACT \\
\hline AMX1066r & AACGTCTCACGACACGAGCTG \\
\hline
\end{tabular}

Table 1. Information of PCR primers used in this study.
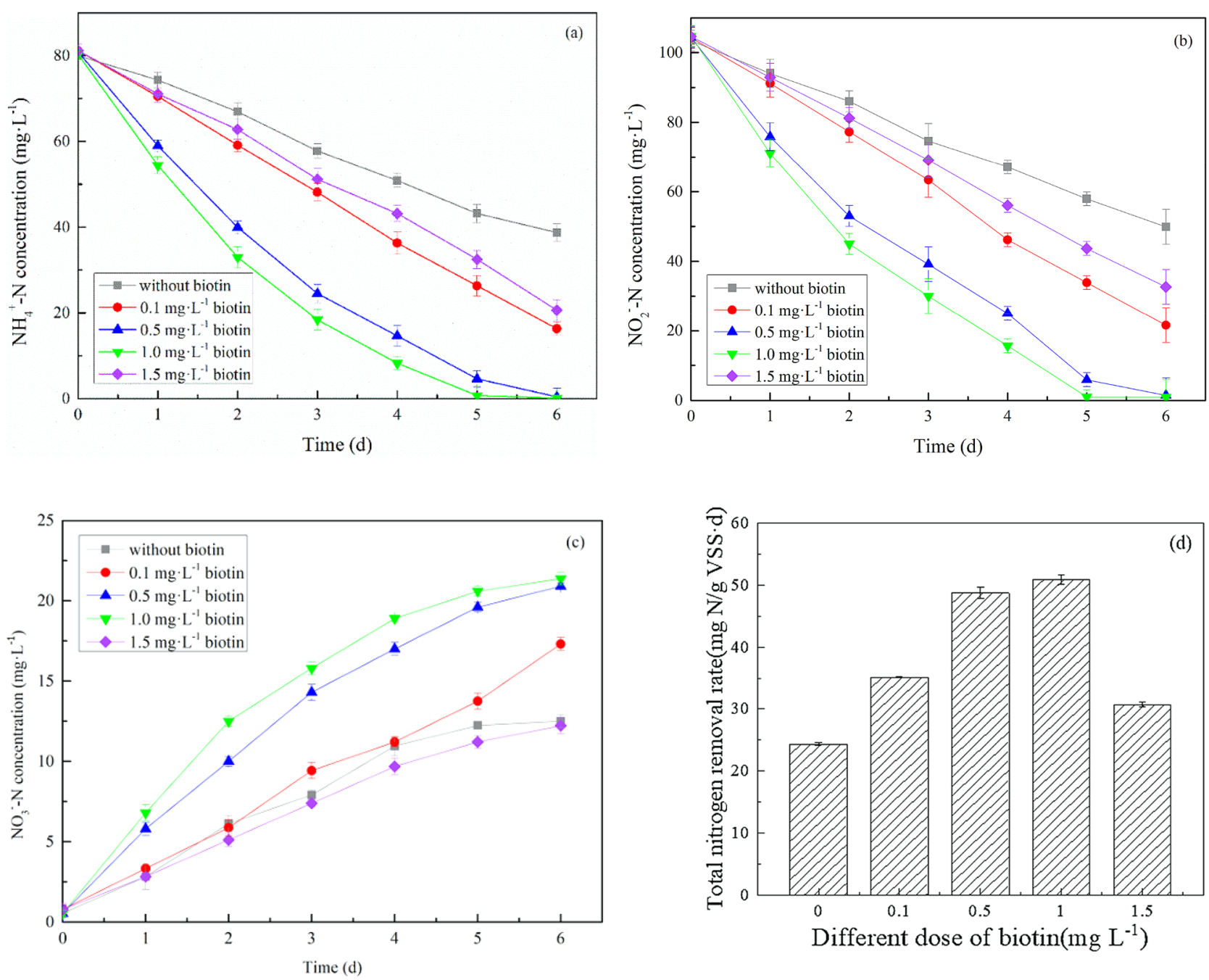

Figure 2. Concentrations of $\mathrm{NH}_{4}{ }^{+}-\mathrm{N}(\mathbf{a}), \mathrm{NO}_{2}^{-}-\mathrm{N}(\mathbf{b})$, and $\mathrm{NO}_{3}{ }^{-}-\mathrm{N}(\mathbf{c})$ with time, and the total nitrogen removal rate at the end of the experiment $(\mathbf{d})$.

\section{Results and discussion}

Nitrogen removal performance. The biotin concentrations added to each group was $0 \mathrm{mg} / \mathrm{L}$ (no biotin, the control group), $0.1 \mathrm{mg} / \mathrm{L}, 0.5 \mathrm{mg} / \mathrm{L}, 1.0 \mathrm{mg} / \mathrm{L}$, and $1.5 \mathrm{mg} / \mathrm{L}$, and the results of the experiments are shown in Fig. 2a-d.

Compared with the control group, we observed a significant increase in the total nitrogen removal efficiency after the addition of biotin (Fig. 2a-c). After six days of cultivation, $\mathrm{NH}_{4}{ }^{+}-\mathrm{N}$ and $\mathrm{NO}_{2}{ }^{-}-\mathrm{N}$ concentrations in the control group declined from 80.0 to $38.8 \mathrm{mg} / \mathrm{L}$ and from 104 to $49.6 \mathrm{mg} / \mathrm{L}$, respectively, and the $\mathrm{NO}_{3}{ }^{-}-\mathrm{N}$ concentration increased to $12.5 \mathrm{mg} / \mathrm{L}$. The $\Delta \mathrm{NH}_{4}{ }^{+}-\mathrm{N}: \Delta \mathrm{NO}_{2}{ }^{-}-\mathrm{N}: \Delta \mathrm{NO}_{3}{ }^{-}-\mathrm{N}$ ratio was 1: 1.31: 0.30, which was approximately in accordance with the anammox physicochemical reaction formula, $1 \mathrm{NH}_{4}{ }^{+}+1.32 \mathrm{NO}_{2}{ }^{-}+0.066$ $\mathrm{HCO}_{3}{ }^{-}+0.13 \mathrm{H}^{+} \rightarrow 1.02 \mathrm{~N}_{2}+0: 26 \mathrm{NO}_{3}{ }^{-}+0.066 \mathrm{CH}_{2} \mathrm{O}_{0.5} \mathrm{~N}_{0.15}+2.03 \mathrm{H}_{2} \mathrm{O}$. In the batch tests, the $\mathrm{NH}_{4}{ }^{+}-\mathrm{N}$ and $\mathrm{NO}_{2}^{-}-\mathrm{N}$ concentrations declined to 1.0 and $0.3 \mathrm{mg} / \mathrm{L}$, respectively, at a biotin dosage of $0.5 \mathrm{mg} / \mathrm{L}$, and to $0.5 \mathrm{mg} / \mathrm{L}$ and $0.1 \mathrm{mg} / \mathrm{L}$ at a biotin dosage of $1.0 \mathrm{mg} / \mathrm{L}$. As the concentration of total inorganic nitrogen changed from $185.6 \mathrm{mg} / \mathrm{L}$ to $21.9 \mathrm{mg} / \mathrm{L}$, the minimum concentrations of $\mathrm{NH}_{4}{ }^{+}-\mathrm{N}$ and $\mathrm{NO}_{2}{ }^{-}-\mathrm{N}$ and the maximum concentration of produced $\mathrm{NO}_{3}{ }^{-}-\mathrm{N}(21.3 \mathrm{mg} / \mathrm{L})$ were observed in the $1.0 \mathrm{mg} / \mathrm{L}$ biotin group; this suggests maximum bacterial activity and optimal biotin concentrations at $1.0 \mathrm{mg} / \mathrm{L}$ biotin. The concentrations of biotin during the cultivation process are shown in Table 2. The results indicated different amounts of biotin loss during the experimental 


\begin{tabular}{|l|l|l|l|l|l|}
\hline \multirow{2}{*}{ Time(day) } & \multicolumn{6}{|l|}{ Biotin concentration $(\mathbf{m g} / \mathbf{L})$} \\
\cline { 2 - 6 } & $\mathbf{0 . 0}$ & $\mathbf{0 . 1}$ & $\mathbf{0 . 5}$ & $\mathbf{1 . 0}$ & $\mathbf{1 . 5}$ \\
\hline 1 & 0.0 & 0.0984 & 0.500 & 1.00 & 1.50 \\
\hline 6 & 0.0 & 0.00450 & 0.0197 & 0.0179 & 0.00990 \\
\hline
\end{tabular}

Table 2. Biotin concentrations during the cultivation process in the experimental system.
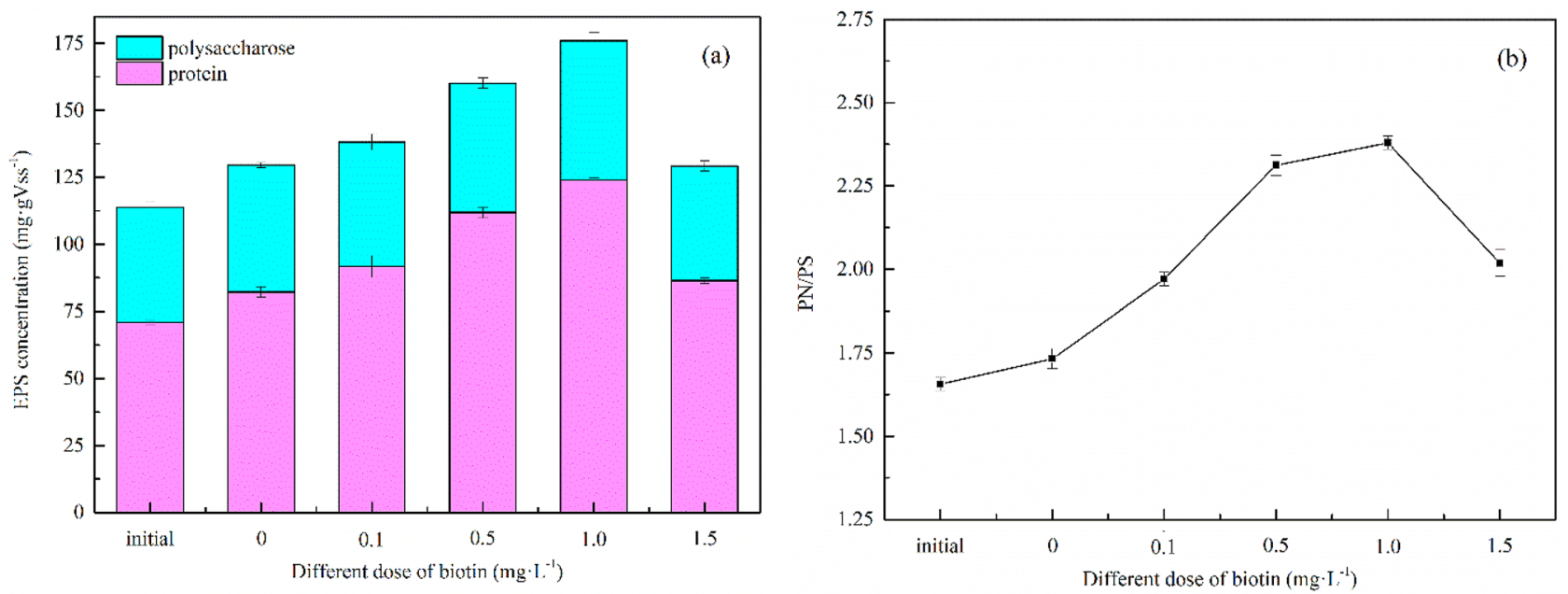

Figure 3. Changes of EPS concentrations (a) and PN/PS ratio (b).

process. This may be attributed to the cell utilization of biotin. Both biotin and enzymes contribute to the metabolic processes of the three main nutrients in cells. For example, the enzyme pyruvate carboxylase uses biotin as a coenzyme in the reaction between pyruvate and succinate during gluconeogenesis. In the process of fatty acid synthesis, biotin acts as a coenzyme of acetyl-CoA carboxylase to catalyze acetyl-CoA and produce malonate$\mathrm{CoA}^{34}$. Biotin plays an important role in protein and purine synthesis as well as the catabolism of tryptophan and leucine. It is also a dominant growth factor for certain microorganisms ${ }^{35}$.

The removal rate of $\mathrm{NH}_{4}{ }^{+}-\mathrm{N}$ and $\mathrm{NO}_{2}{ }^{-}-\mathrm{N}$ gradually reduced during the experiment at initial biotin concentrations of $0.5 \mathrm{mg} / \mathrm{L}$ and $1.0 \mathrm{mg} / \mathrm{L}$ (Fig. 2a,b). This can also be attributed to the gradual decrease in biotin concentration, which reduced its anammox bacterial activity stimulation.

Under the optimum biotin dose $(1.0 \mathrm{mg} / \mathrm{L})$, the average NRR was $50.9 \mathrm{mg} \mathrm{N} \mathrm{g}^{-1} \mathrm{VSS}_{\text {day }}{ }^{-1}$, and the NRR was $112 \%$ higher than the control group (Fig. 2d). We also observed no prominent enhancement of anammox bacterial activity at a biotin dose of $1.5 \mathrm{mg} / \mathrm{L}$. Combined with the analysis of bacterial community structure, we infer the consumption of biotin by heterotrophic bacteria (Thaurea genus of Proteobacteria phylum, Micromonospora genus of Actinobacteria phylum, etc.) in the reaction system, which negatively impacted biotin stimulation on anammox bacterial activity. This suggests that higher biotin concentrations may have promoted the growth of heterotrophic bacteria and influenced the original anammox system. These results highlight the need for optimal concentrations of biotin within 0.1 to $1.5 \mathrm{mg} / \mathrm{L}$ to enhance anammox bacterial activity appropriately. The NRR in this study was higher than that of other previous studies on nitrogen removal performance by anammox bacteria $^{36-39}$, which suggests that biotin addition can effectively enhance anammox bacterial activity.

EPS analysis. Anammox bacteria tend to secrete a significant amount of EPS during their growth process; this largely impacts the physical and chemical properties of microbial polymers, such as flocculation, stability, and adsorption, and thus influences the activity of anammox bacteria sludge ${ }^{40,41}$. EPS is a metabolic product that accumulates on the surface of bacterial cells; the layer of PN and PS, the main components of EPS, protects cells from the external environment ${ }^{42}$. In this study, we assessed the effect of biotin on anammox bacterial activity by detecting changes in EPS concentrations (Fig. 3).

The initial concentrations of PN and PS in the sludge were 70.9 and $42.8 \mathrm{mg} \mathrm{gVSS}^{-1}$, respectively. Without biotin, the total EPS of the control group increased by $14.1 \%$ after 6 days of culture, and its content reached $130 \mathrm{mg} \mathrm{gVSS}^{-1}$. Compared with the control group, EPS significantly increased by $21.5 \%, 40.8 \%$, and $54.8 \%$ at biotin concentrations of $0.1,0.5$, and $1.0 \mathrm{mg} / \mathrm{L}$, respectively. PN, PS, and EPS contents were the highest (124, 52.1 , and $177 \mathrm{mg} \mathrm{gVSS}^{-1}$, respectively) at a biotin concentration of $1.0 \mathrm{mg} / \mathrm{L}$. However, the total EPS was $132 \mathrm{mg}$ $\mathrm{gVSS}^{-1}\left(86.4 \mathrm{mg} \mathrm{gVSS}^{-1} \mathrm{PN}, 42.8 \mathrm{mg} \mathrm{gVSS}^{-1} \mathrm{PS}\right.$ ) at a biotin dose of $1.5 \mathrm{mg} / \mathrm{L}$, which was similar to the results of the control group (without biotin). We therefore infer the consumption of biotin by heterotrophic bacteria in the reaction system under this biotin dosage. Moreover, heterotrophic bacteria may also use the original EPS in the system as a carbon source during their own proliferation and growth. 


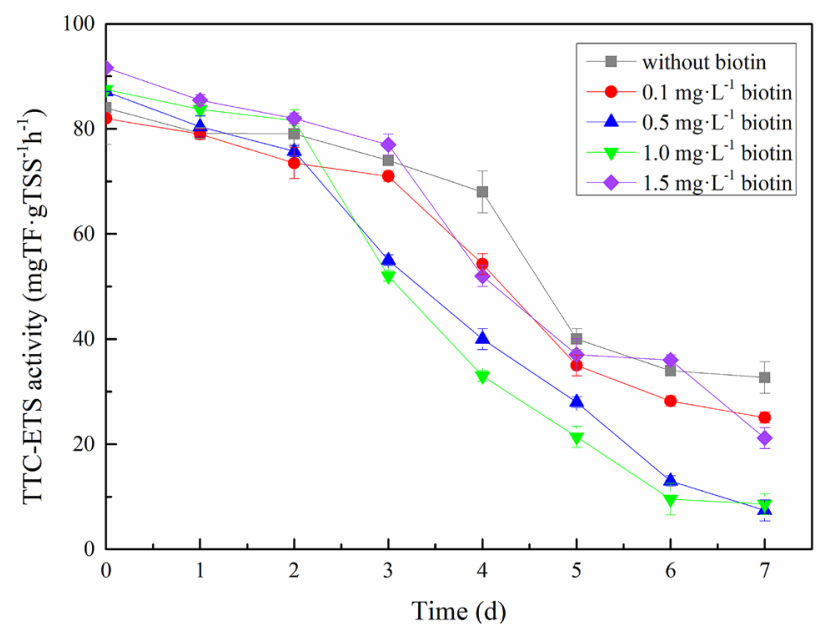

Figure 4. TTC-ETS activity under various biotin doses.

EPS can promote the physical bridging effect in microbial cell aggregation by changing the negative charge on the surface of bacteria; it can also help to form the porous structure of sludge ${ }^{43}$ (sludge granulation), which improves the stability of the system and the activity of anammox bacteria ${ }^{44}$. We found that higher biotin dosages (from 0.1 to $1.0 \mathrm{mg} / \mathrm{L}$ ) increased the production of EPS by anammox bacteria. Moreover, a biotin dosage of $1.0 \mathrm{mg} / \mathrm{L}$ had the strongest enhancing effect on EPS production. Gao et al. showed that highly active anammox bacteria secreted more EPS ${ }^{45}$, which is consistent with the positive correlation between EPS yield and anammox bacterial activity in this experiment. The PN/PS ratio is also an important indicator of sludge properties, which reflects the sedimentation property of microorganisms ${ }^{46}$. In our study, the PN/PS ratio of each sample was higher than that of the control group. PN/PS gradually increased and reached a maximum value of 2.38 at $1.0 \mathrm{mg} / \mathrm{L}$ biotin; however, the sludge performance showed no significant changes. The change in PN/PS may have therefore been insufficient to exert a significant impact on sludge performance.

ETS activity analysis. During aerobic or anaerobic microbial respiration, electrons are passed through a series of electron carriers to the final electron acceptor to remove organic pollutants. These electronic carriers are arranged in the order of increasing electron affinity, which constitutes the ETS. The ETS activity of sludge is an index of the microbial ability to reduce the number of artificial electron acceptors (redox potential is lower than that of natural ultimate electron acceptors) under certain conditions ${ }^{47}$. Measurements of electron transfer rates on the respiratory chain of sludge microorganisms can therefore indirectly characterize the microbial activity in sludge ${ }^{30}$. More hydrogen (electrons) transferred to the final electron acceptor through the peroxidation respiration chain per unit time infers a faster microbial respiration rate and higher biological activity in sludge, and vice versa. Triphenyltetrazolium chloride (TTC) is often used as an artificial electron receptor to detect ETS activity $^{48}$. TTC-ETS activity is therefore the ETS activity detected by TTC and is shown in Fig. 4.

We observed a decrease in TTC-ETS activity with decreasing substrate before the complete consumption of the internal substrate. Following complete substrate consumption after 6 days with 0.5 and $1.0 \mathrm{mg} / \mathrm{L}$ biotin addition, TTC-ETS activity rapidly decreased to its lowest level and remained stable, indicating the complete removal of $\mathrm{NH}_{4}{ }^{+}-\mathrm{N}$ and $\mathrm{NO}_{2}{ }^{-}-\mathrm{N}$ in the system. The decrease in TTC-ETS activity in the 0.5 and $1.0 \mathrm{mg} / \mathrm{L}$ biotin groups occurred earlier and was more significant than the other biotin groups; this suggests a more rapid substrate consumption and higher biological activity in the anammox sludge of these two groups. Our TTC-ETS findings therefore indicate the removal of substrate $\left(\mathrm{NH}_{4}{ }^{+}-\mathrm{N}, \mathrm{NO}_{2}{ }^{-}-\mathrm{N}\right)$, which is in line with our results on nitrogen removal performance. This observation is consistent with previous studies ${ }^{49,50}$ that reported a positive relationship between substrate $\left(\mathrm{NH}_{4}{ }^{+}-\mathrm{N}\right)$ removal and TTC-ETS activity in sludge. However, TTC-ETS activity in the $0,0.1$, and $1.5 \mathrm{mg} / \mathrm{L}$ biotin groups did not reach the minimum value, indicating incomplete substrate reaction and consumption. Moreover, the electron transfer process was still active, inferring low biological activity in the anammox sludge of these three groups.

Heme analysis. Heme concentration was positively correlated with the nitrogen removal performance of anammox sludge, which directly reflects the sludge anammox activity ${ }^{51}$. In this study, we used a fluorescence spectrometer to measure the fluorescence intensity at an excitation wavelength of $405 \mathrm{~nm}$ and an emission wavelength of 500-700 nm. The characteristic peak fluorescence intensity of heme ferrous was detected at $601.4 \mathrm{~nm}$ and $655 \mathrm{~nm}$. We then calculated the heme ferrous content in the anammox sludge from the standard curve.

As shown in Table 3, heme content also increased with increasing biotin concentration within 0-1.0 mg/L biotin. The $1.0 \mathrm{mg} / \mathrm{L}$ biotin group showed the highest heme content at $2.67 \mathrm{mg} \mathrm{gVSS}^{-1}$, which increased by $43.8 \%$ of the initial value at $1.86 \mathrm{mg} \mathrm{gVSS}^{-1}$, indicating the highest biological activity. The heme content in the $1.5 \mathrm{mg} / \mathrm{L}$ biotin group $\left(2.39 \mathrm{mg} \mathrm{gVSS}^{-1}\right.$ ) was lower than that of the $1.0 \mathrm{mg} / \mathrm{L}$ biotin group, which is consistent with the results of nitrogen removal performance. Previous studies ${ }^{51,52}$ reported a positive correlation between heme concentration and NRR at $35^{\circ} \mathrm{C}$. Moreover, Chen et al. observed an increase in heme concentration with 


\begin{tabular}{|l|l|l|l|l|l|}
\hline Sample & $\begin{array}{l}\mathbf{6 0 1 . 4} \mathbf{~ n m} \\
\text { (A.U.) }\end{array}$ & $\begin{array}{l}\mathbf{6 5 5} \mathbf{~ n m} \\
\text { (A.U.) }\end{array}$ & $\begin{array}{l}\mathbf{6 0 1 . 4} \mathbf{~ n m} \\
\text { (mg/gVSS) }\end{array}$ & $\begin{array}{l}\mathbf{6 5 5} \mathbf{~ n m} \\
\text { (mg/gVSS) }\end{array}$ & $\begin{array}{l}\text { average } \\
\text { (mg/gVSS) }\end{array}$ \\
\hline initial & 190 & 129 & 1.82 & 1.90 & 1.86 \\
\hline $0 \mathrm{mg} / \mathrm{L}$ & 207 & 137 & 2.24 & 2.19 & 2.21 \\
\hline $0.1 \mathrm{mg} / \mathrm{L}$ & 215 & 146 & 2.45 & 2.46 & 2.46 \\
\hline $0.5 \mathrm{mg} / \mathrm{L}$ & 217 & 147 & 2.49 & 2.49 & 2.48 \\
\hline $1.0 \mathrm{mg} / \mathrm{L}$ & 231 & 147 & 2.83 & 2.52 & 2.67 \\
\hline $1.5 \mathrm{mg} / \mathrm{L}$ & 213 & 143 & 2.40 & 2.38 & 2.39 \\
\hline
\end{tabular}

Table 3. Fluorescence intensity and concentration of heme.

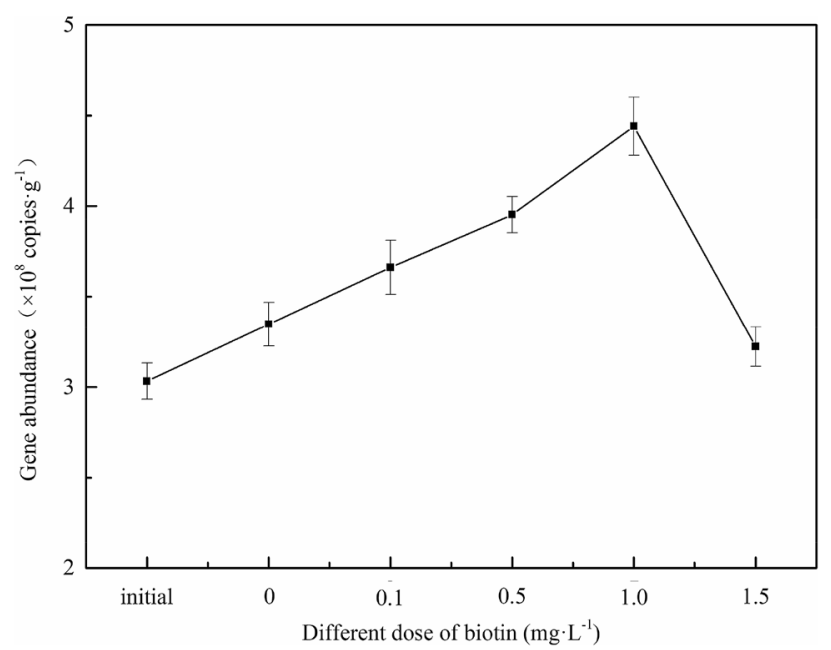

Figure 5. Anammox bacteria gene abundance under different biotin doses.

increasing nitrogen removal capacity during the start-up period of an anammox process ${ }^{53}$. These results are in agreement with the observed positive correlation between heme and NRR in this study. NRR reached the highest value of $50.9 \mathrm{mg} \mathrm{N} \mathrm{g}^{-1} \mathrm{VSS}$ day $^{-1}$ in the $1.0 \mathrm{mg} / \mathrm{L}$ biotin group, which suggests that $1.0 \mathrm{mg} / \mathrm{L}$ biotin is the optimum concentration (within the selected gradient) for the growth and activity of anammox bacteria.

qPCR results. We conducted real-time qPCR to determine the gene abundance of anammox bacteria before and after biotin addition, as shown in Fig. 5. The abundance of anammox bacteria gradually increased with increasing biotin concentration. Moreover, the copy number of the functional genes of anammox bacteria in the $1.0 \mathrm{mg} / \mathrm{L}$ biotin group showed the most significant increase from $3.03 \times 10^{8}$ to $4.44 \times 10^{8}$ copies/g dry sludge (or a $46.5 \%$ increase). Biotin addition therefore notably accelerated the growth of anammox bacteria. This may be owing to biotin's nitric oxide (NO)-like function, which increases the intracellular concentration of the second messenger cGMP (through the activation of the soluble form of the enzyme guanylate cyclase (sGC)) and improves the rate of cell division ${ }^{54,55}$. However, the abundance of functional genes of anammox bacteria in the $1.5 \mathrm{mg} / \mathrm{L}$ biotin group $\left(3.22 \times 10^{8}\right.$ copies/g dry sludge $)$ was similar to that of the non-biotin group $\left(3.35 \times 10^{8}\right.$ copies/g dry sludge); this was likely linked to the consumption of biotin by heterotrophic bacteria in the reaction system, which inhibited the biotin stimulation of anammox bacteria.

Community structure analysis. To investigate the influence of biotin on the anammox bacteria community structure, the anammox sludge in the reactor was sampled for high-throughput sequencing. Samples S1-S5 represent the anammox sludge with biotin additive dosages of $0,0.1,0.5,1.0$, and $1.5 \mathrm{mg} / \mathrm{L}$, respectively; S6 was the original sludge without biotin addition.

The microbial community has been in a dynamic process for a long period, and the microbial community structure may have changed with the addition of external substances. To date, five genera of anammox bacteria have been reported-Kuenenia, Brocadia, Jettenia, Scalindua, and Anammoxoglobus-all of which are affiliated with Planctomycetes ${ }^{56}$. According to the diversity index of microorganisms in Table 4, the microbial diversity in the five groups of reactors with biotin was significantly lower than that of the original sludge. S6 showed the highest microbial diversity index, with various bacteria occupying a stable ecological niche in the original system, indicating ecosystem stability. The microbial diversity index of the biotin-stimulated samples showed a decreasing trend, with S4 (with $1.0 \mathrm{mg} / \mathrm{L}$ biotin) showing the lowest diversity. 


\begin{tabular}{|l|l|l|l|l|l|l|}
\hline Sample Name & Observed species & Shannon & Simpson & Chaol & ACE & Goods coverage \\
\hline S1 & 460 & 6.04 & 0.963 & 478 & 485 & 0.999 \\
\hline S2 & 420 & 4.57 & 0.808 & 470 & 452 & 0.998 \\
\hline S3 & 460 & 5.42 & 0.891 & 494 & 493 & 0.998 \\
\hline S4 & 433 & 5.42 & 0.922 & 453 & 462 & 0.999 \\
\hline S5 & 467 & 6.09 & 0.961 & 519 & 501 & 0.998 \\
\hline S6 & 537 & 6.68 & 0.976 & 557 & 566 & 0.999 \\
\hline
\end{tabular}

Table 4. Sludge sample sequencing information and microbial diversity index.

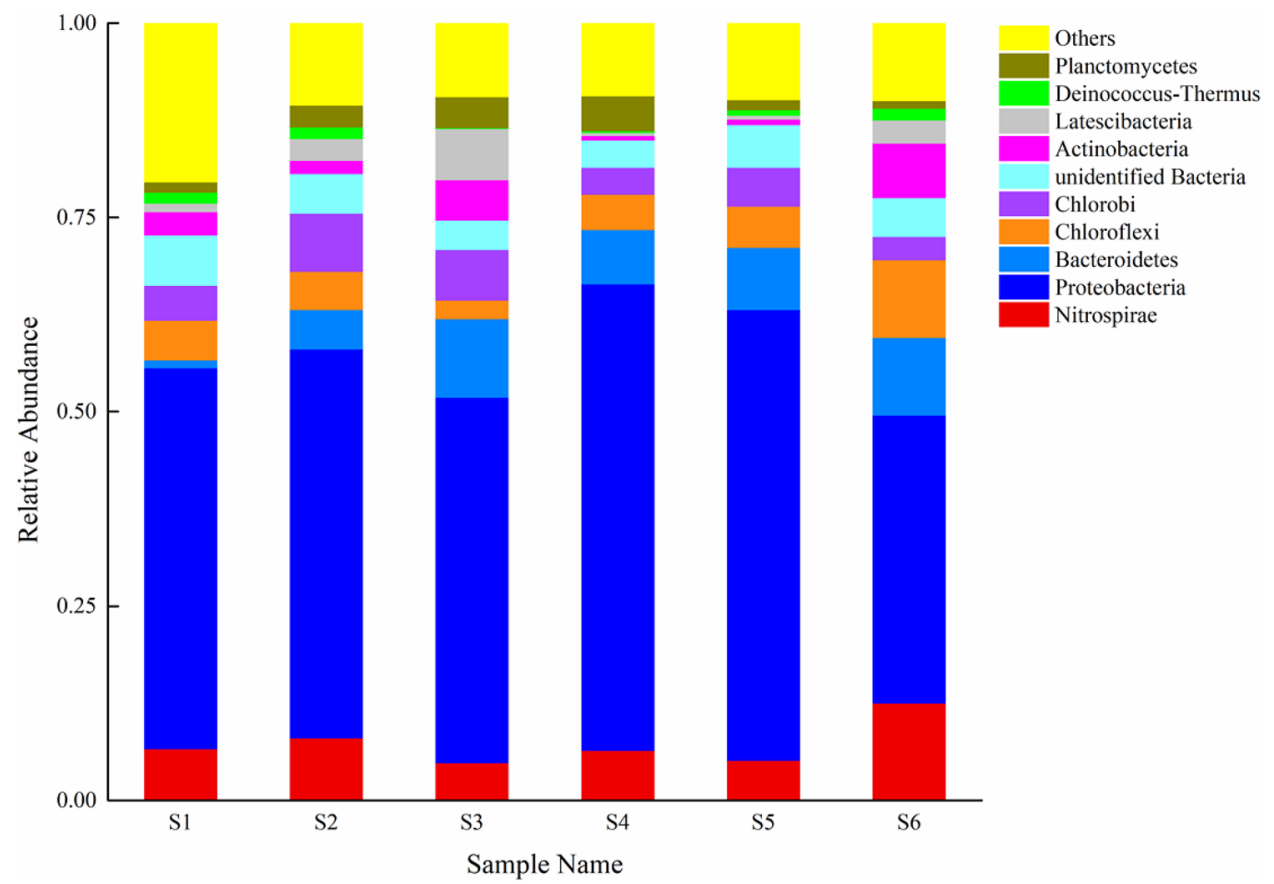

Figure 6. Taxonomic classification (phylum level) of the bacterial communities in each sludge sample (S1-S5).

A histogram of the 10 most abundant species in each sample (based on $16 \mathrm{~S}$ rDNA amplicon sequencing at the phylum classification level) is shown in Fig. 6.

The bacterial community structure of the sludge in the reactor changed significantly following the addition of different biotin doses (Fig. 6). In the original sludge, the main bacteria were Nitrospirae, Proteobacteria, Bacteroidetes, and Chloroflexi. Proteobacteria accounted for the largest proportion in all six samples, ranging from 61.7 to $77.9 \%$. The number of Planctomycetes bacteria increased gradually with increasing biotin, indicating the positive effect of biotin on Planctomycetes growth and proliferation. Nitrogen-removing microorganisms were mainly from Proteobacteria, Nitrospiare, and Planctomycetes, which accounted for $50.5 \%-70.9 \%$ of the total bacteria after biotin addition. Nitrogen removal efficiency therefore improved with biotin addition, reaching $88.4 \%$ at $1.0 \mathrm{mg} / \mathrm{L}$ biotin.

Three major genera were detected in Planctomycetes, of which Candidatus Brocadia and Candidatus Jettenia were anammox bacteria. The proportions of Candidatus Brocadia and Candidatus Jettenia in the inoculated sludge were $1.3 \%$ and $1.7 \%$, respectively. After cultivation with biotin, Candidatus Brocadia gradually increased to $1.9 \%$ (exceeding Candidatus Jettenia at $0.1 \%$ ) and was therefore the dominant genus of anammox bacteria in the reactor. Candidatus Jettenia can only live at low nitrogen loading rates, whereas Candidatus Brocadia has a higher proliferation rate at high nitrogen loading rates ${ }^{57}$. The change in nitrogen loading rate may therefore be the cause for the change in the dominant anammox strains. However, further analysis is required to elucidate the cause of bacterial species changes during the anammox enrichment process.

\section{Conclusions}

We found that the addition of biotin within a limited gradient promoted biological activity and enhanced the biomass of anammox bacteria in short-term batch tests. The anammox activity showed the most significant improvement in the $1.0 \mathrm{mg} / \mathrm{L}$ biotin group, with a NRR increase of $112 \%$ compared with the control. This group also produced the highest concentration of total EPS and heme, with an increase of 54.8\% and $43.8 \%$, respectively, compared with their initial contents. The largest decrease in TTC-ETS activity was also observed 
in the $1.0 \mathrm{mg} / \mathrm{L}$ biotin group, indicating the highest biological activity in the anammox sludge of this group. The maximum abundance of anammox bacteria also increased by $46.4 \%$. The predominant anammox bacteria were Candidatus Brocadia, whereas the abundance of Candidatus Jettenia gradually decreased with increasing biotin supplementation.

Received: 17 November 2020; Accepted: 11 January 2021

Published online: 21 January 2021

\section{References}

1. Strous, M. et al. Missing lithotroph identified as new planctomycete. Nature 400, 446-449 (1999).

2. Tenno, T., Uiga, K., Mashirin, A., Zekker, I. \& Rikmann, E. Modeling closed equilibrium systems of $\mathrm{H}_{2} \mathrm{O}$-Dissolved $\mathrm{CO}_{2}$-solid $\mathrm{CaCO}_{3}$. J. Phys. Chem. A 121, 3094-3100 (2017).

3. Rikmann, E., Zekker, I., Tenno, T., Saluste, A. \& Tenno, T. Inoculum-free start-up of biofilm- and sludge-based deammonification systems in pilot scale. Int. J. Environ. Sci. Technol. 15, 133-148 (2018).

4. Kimura, Y., Isaka, K. \& Kazama, F. Effects of inorganic carbon limitation on anaerobic ammonium oxidation (anammox) activity. Bioresour. Technol. 102, 4390-4394 (2011).

5. Lackner, S. et al. Full-scale partial nitritation/anammox experiences-An application survey. Water Res. 55, 292-303 (2014).

6. Strous, M., Heijnen, J. J., Kuenen, J. G. \& Jetten, M. The sequencing batch reactor as a powerful tool for the study of slowly growing anaerobic ammonium-oxidizing microorganisms. Appl. Microbiol. Biot. 50, 589-596 (1998).

7. Kartal, B., van Niftrik, L., Keltjens, J. T., Op den Camp, H. J. \& Jetten, M. S. Anammox-growth physiology, cell biology, and metabolism. Adv. Microb. Physiol. 60, 212-262 (2012).

8. Jin, R., Yang, G., Yu, J. \& Zheng, P. The inhibition of the Anammox process: a review. Chem. Eng. J. 197, 67-79 (2012).

9. Zekker, I. et al. Nitric oxide for anammox recovery in a nitrite-inhibited deammonification system. Environ. Sci. Tech. Let. 36, 2477-2487 (2015).

10. Zhang, Z. et al. Evaluation of the inhibitory effects of heavy metals on anammox activity: a batch test study. Bioresour. Technol. 200, 208-216 (2016).

11. Raudkivi, M. et al. Nitrite inhibition and limitation-the effect of nitrite spiking on anammox biofilm, suspended and granular biomass. Water Sci. Technol. 75, 313-321 (2017).

12. Kocamemi, B. A. et al. Anammox start-up strategies: the use of local mixed activated sludge seed versus Anammox seed. Water Sci. Technol. 78, 1901-1915 (2018).

13. Miao, Y., Zhang, J., Peng, Y. \& Wang, S. An improved start-up strategy for mainstream anammox process through inoculating ordinary nitrification sludge and a small amount of anammox sludge. J. Hazard. Mater. 12, 13-25 (2019).

14. Yang, S. et al. The value of floc and biofilm bacteria for anammox stability when treating ammonia-rich digester sludge thickening lagoon supernatant. Chemosphere 233, 472-481 (2019).

15. Ren, J. et al. ANAMMOX reactor with two kinds of inoculated sludge: start-up and kinetics characteristics. Huanjing Kexue 3, 1405-1411 (2019).

16. Kowalski, M. S., Devlin, T. R., di Biase, A. \& Oleszkiewicz, J. A. Effective nitrogen removal in a two-stage partial nitritationanammox reactor treating municipal wastewater-piloting PN-MBBR/AMX-IFAS configuration. Bioresour. Technol. 289, 121742 (2019).

17. Rios-Del Toro, E. E., Lpez-Lozano, N. \& Cervantes, F. J. Up-flow anaerobic sediment trapped (UAST) reactor as a new configuration for the enrichment of anammox bacteria from marine sediments. Bioresour. Technol. 238, 528-533 (2017).

18. Tao, Y., Gao, D., Fu, Y., Wu, W. \& Ren, N. Impact of reactor configuration on anammox process start-up: MBR versus SBR. Bioresource Technol. 104, 73-80 (2012).

19. Strous, M., Van Gerven, E. \& Zheng, P. Ammonium removal from concentrated waste streams with the anaerobic ammonium oxidation (Anammox) process in different reactor configurations. Water Res. 8, 1955-1962 (1997).

20. Pereira, A. D., Cabezas, A., Etchebehere, C., Chernicharo, C. \& de Araújo, J. C. Microbial communities in anammox reactors: a review. Environ. Technol. Rev. 8, 74-93 (2017).

21. Ni, L., Lin, X., Yan, H. \& Wang, Y. A novel anammox granules-circulating expanded granular sludge bed reactor for the efficient circulation and retention of floating anammox granules. Chemosphere 235, 316-326 (2019).

22. León-Del-Río, A. Biotin in metabolism, gene expression, and human disease. J. Inherit. Metab. Dis. 42, 647-654 (2019).

23. Baur, B. \& Baumgartner, E. Biotin in metabolism, gene expression, and human disease. Brain Res. 858, 348-355 (2019).

24. Rose, R. et al. Transport and metabolism of vitamins. Federation Proc. 45, 30-39 (1986).

25. Yang, G. Reactivation of effluent granular sludge from a high-rate Anammox reactor after storage. Biodegradation 24, 13-32 (2013).

26. APHA, 2012. Standard Methods for the Examination of Water and Wastewater, twentieth ed. American Public Health Association(APHA), Washington, DC, USA.

27. Yu, H., Wang, Z., Wang, Q., Wu, Z. \& Ma, J. Disintegration and acidification of MBR sludge under alkaline conditions. Chem. Eng. J. 231, 206-213 (2013).

28. Lowry, O., Rosebrough, N. \& Farr, A. Protein measurement with the Folin phenol reagent. J. Biol. Chem. 193, 265-275 (1951).

29. Dubois, M., Gilles, K. \& Hamilton, J. Colorimetric method for determination of sugars and related substances. Anal. Chem. 28, 350-356 (1956).

30. Trevors, J., Mayfield, C. \& Inniss, W. Measurement of electron transport system (ETS) activity in soil. Microb. Ecol. 8, 163-168 (1982).

31. Meng, F., Meng, Y. \& Zhou, Z. A method for extraction and determination of heme from anammox sludge, CN, 10278495.8 [P/ $\mathrm{OL}]$.

32. Qi, L. et al. Determination of biotin in infant, pediatric, and adult nutritionals by high-performance liquid chromatography and fluorescence detection: single-laboratory validation, first action 2016.11. J. Aoac. Int. 100, 145-151 (2017).

33. Tsushima, I., Kindaichi, T. \& Okabe, S. Quantification of anaerobic ammonium-oxidizing bacteria in enrichment cultures by real-time PCR. J. Environ. Sci. 11, 1557-1561 (2009).

34. Jrvinen, E. et al. Biotin-dependent functions in adiposity: a study of monozygotic twin pairs. Int. J. Obes. 40, 788-795 (2016).

35. Polyak S. \& Chapman-Smith A. In Biotin 221-225 (Encyclopedia of Biological Chemistry, 2013).

36. Xu, X. et al. Effects of gibberellin on the activity of anammox bacteria. J. Environ. Manag. 225, 104-111 (2018).

37. Wang, T., Zhang, H. \& Yang, F. Performance of Anammox process and low-oxygen adaptability of Anammox biofilms in a FBR with small ring non-woven carriers. Ecol. Eng. 86, 126-134 (2016).

38. Yin, X., Qiao, S. \& Zhou, J. Using electric field to enhance the activity of anammox bacteria. Appl. Microbiol. Biot. 99, 6921-6930 (2015).

39. Yang, Z., Zhu, W., Yu, D., Bo, Y. \& Li, J. Enhanced carbon and nitrogen removal performance of simultaneous anammox and denitrification (SAD) with mannitol addition treating saline wastewater. J. Chem. Technol. Biot. 94, 377-388 (2019).

40. Hou, X., Liu, S. \& Zhang, Z. Role of extracellular polymeric substance in determining the high aggregation ability of anammox sludge. Water Res. 75, 51-62 (2015). 
41. Peeters, S. \& van Niftrik, L. Trending topics and open questions in anaerobic ammonium oxidation. Curr. Opin. Chem. Biol. 49, 45-52 (2019).

42. Wang, W., Yan, Y., Zhao, Y., Shi, Q. \& Wang, Y. Characterization of stratified EPS and their role in the initial adhesion of anammox consortia. Water Res. 169, 115223 (2020).

43. Jia, F. et al. Stratification of extracellular polymeric substances (EPS) for aggregated anammox microorganisms. Environ. Sci. Technol. 51, 3260-3268 (2017).

44. Zhang, J. et al. Mechanism of stable sewage nitrogen removal in a partial nitrification-anammox biofilm system at low temperatures: microbial community and EPS analysis. Bioresource Technol. 297, 122459 (2017).

45. Gao, X. et al. Effects of different substrate concentrations on the short-term storage of ANAMMOX bacteria. Huan Jing Ke Xue 39, 5587-5595 (2018).

46. Wu, J., Zhou, H., Li, H., Zhang, P. \& Jiang, J. Impacts of hydrodynamic shear force on nucleation of flocculent sludge in anaerobic reactor. Water Res. 43, 3029-3036 (2009).

47. Yin, J., Tan, X. \& Ren, N. Evaluation of TTC and INT-electron transport system activity tests for heavy metal inhibition of activated sludge. Environ. Sci. 26, 56-62 (2005).

48. Ryssov-Nielsen, H. Measurement of the inhibition of respiration in activated sludge by a modified determination of the ttcdehydrogenase activity. Water Res. 9, 1179-1185 (1975).

49. Wang, W. et al. Long-term effects of $\mathrm{Ni}$ (II) on the performance and activity of activated sludge processes. Ecotox. Environ. Safe. 92, 144-149 (2013).

50. Yang, S. et al. Economical evaluation of sludge reduction and characterization of effluent organic matter in an alternating aeration activated sludge system combining ozone/ultrasound pretreatment. Bioresource Technol. 177, 194-203 (2013).

51. Ma, H., Zhang, Y., Xue, Y., Zhang, Y. \& Li, Y. Relationship of heme c, nitrogen loading capacity and temperature in anammox reactor. Sci. Total. Environ. 659, 568-577 (2019).

52. Zhang, Z., Cheng, Y., Zhou, Y., Buayi, X. \& Jin, R. A novel strategy for accelerating the recovery of an anammox reactor inhibited by copper(II): EDTA washing combined with biostimulation via low-intensity ultrasound. Chem. Eng. J. 279, 912-920 (2015).

53. Chen, H., Hu, H., Chen, Q., Shi, M. \& Jin, R. Successful start-up of the anammox process: influence of the seeding strategy on performance and granule properties. Bioresource Technol. 211, 594-602 (2015).

54. Spence, J. \& Koudelka, A. Effects of biotin upon the intracellular level of cGMP and the activity of glucokinase in cultured rat hepatocytes. J. Biol. Chem. 259, 6393-6408 (1984).

55. Vesely, D. Biotin enhances guanylate cyclase activity. Science 216, 1329-1330 (1982).

56. Jetten, M., Op den Camp, H., Kuenen, J. \& Strous, M. Description of the order Brocadiales. In Bergey's Manual of 506-603 (Heidelberg, 2010).

57. Zhang, L. et al. Microbial competition among anammox bacteria in nitrite-limited bioreactors. Water Res. 125, 249-258 (2017).

\section{Acknowledgements}

This work was supported by the Fundamental Research Funds for the Central Universities, and the Research Funds of Renmin University of China (No. 2020030257).

\section{Author contributions}

G.-h.L. and X.X. designed the research; Q.L. and J.C. performed the experiment and wrote the article; Y.W. and J.Y. analyzed the data; Q.Z. and Y.L. drafted the manuscript; H.W. and L.Q. revised the manuscript. All authors reviewed the manuscript.

\section{Competing interests}

The authors declare no competing interests.

\section{Additional information}

Correspondence and requests for materials should be addressed to G.L. or X.X.

Reprints and permissions information is available at www.nature.com/reprints.

Publisher's note Springer Nature remains neutral with regard to jurisdictional claims in published maps and institutional affiliations.

(c) (i) Open Access This article is licensed under a Creative Commons Attribution 4.0 International License, which permits use, sharing, adaptation, distribution and reproduction in any medium or format, as long as you give appropriate credit to the original author(s) and the source, provide a link to the Creative Commons licence, and indicate if changes were made. The images or other third party material in this article are included in the article's Creative Commons licence, unless indicated otherwise in a credit line to the material. If material is not included in the article's Creative Commons licence and your intended use is not permitted by statutory regulation or exceeds the permitted use, you will need to obtain permission directly from the copyright holder. To view a copy of this licence, visit http://creativecommons.org/licenses/by/4.0/.

(C) The Author(s) 2021 